\title{
Effects of Socio-Economic and Occupation on Beneficiary and non-Beneficiary Water-shed Management Catchment Areas in the State of Nagaland, India
}

\author{
Mukesh Kumar Yadav and Amod Sharma* \\ Department of Agricultural Economics, Nagaland University SASRD Medziphema Campus, \\ District: Dimapur - 797 106, Nagaland, India \\ *Corresponding author
}

A B S T R A C T

Keywords

Socio, economic, beneficiaries, nonbeneficiaries, activities.

Article Info

Accepted:

18 August 2019

Available Online:

10 September 2019
The present study to access the socio-economic aspects of beneficiaries and non-beneficiary on watershed management implemented with especial reference to the purpose in selected both districts from the Nagaland state viz; Dimapur and Kohima; as both were selected purposely due to the maximum number of area covered under watershed in the zone further two blocks from each district were randomly selected, which was finally having 8 numbers of watersheds areas were selected. In the second stage of sampling a multi stage random sampling was used for the selection of beneficiary and non-beneficiary viz; 160 respondents (80 beneficiaries and 80 non-beneficiaries) were selected randomly from identified watershed areas. Further the beneficiaries were doing primary, secondary and tertiary occupation on small and medium group, were as large were engaged as primary and secondary occupation only.

\section{Introduction}

Nagaland, the $16^{\text {th }}$ State of the Indian Union, came into being on $01^{\text {st }}$ December 1963. Nagaland with a geographical area of about $16,579 \mathrm{Sq}$. Km. lies between $25^{\circ} 60^{\prime}$ and $27^{\circ} 40^{\prime}$ North latitude and $93^{\circ} 20^{\prime}$ and $95^{\circ} 15^{\prime}$ East longitude. The state is bounded by Assam in the North and West, by Myanmar and Arunachal Pradesh in the East and by Manipur in the South. Nagaland, being one of the
"Eight Sisters" commonly called as the North-Eastern Region including Sikkim, is a land of lush green forests, rolling Mountains, enchanting valleys, swift flowing streams and of beautiful landscape. The inhabitants of Nagaland are almost entirely tribal with distinctive dialects and cultural features (Annon., 2017).

Agriculture is the backbone of Indian economy and largely dependent on natural 
resources likes soil, water and vegetation. Indian agriculture is to transform rain-fed farming into more sustainable and productive system to better support the population dependent upon it (Walling et.al., 2017). Out of the 142 million ha of cultivated land in India, 105 million ha under tainted agriculture, which contributes 44.00 per cent of total food basket and supporting 40.00 per cent of the production (Annon. 2016).

Watershed management activities is the process of guiding and organizing land, soil and other resource use on a watershed to provide needed goods and services and simultaneously conserving soil, water and land natural resources. The interrelationships among soil land used and water, and the linkages between up-stream and downstream area are given an explicit significance in watershed approach. Water shad management focuses on using resources in a productive and sustainable manner. The Government of Nagaland has launched many watershed projects financed by national and international donor agencies with a view to rehabilitate the degraded environment and improve the economy of the state (Walling and Sharma, 2015).

Watershed is defined as a hydro-geological unit area from which the rainwater drains through a single outlet. Watershed development refers to the conservation, regeneration and judicious use of all the natural resources (like land, water, plants, animals) by human beings (Sharma et.al., 2015).

A watershed provides a natural geohydrological unit for planning any developmental initiative (Sharma, 2012; Tangjang and Sharma, 2018). The approach would be treatment from "ridge to valley". The present study having the two specific objectives viz; To evaluate the resource use- efficiency of the sample farmers, and to study the marginal value product of Integrated Watershed Management Programme.

\section{Materials and Methods}

For the present study In the first stage two districts were selected purposively viz; Dimapur and Kohima due to the maximum areas and catchment areas, while in the second stage of sampling a multi stage random sampling was used for the selection of beneficiary and non-beneficiary viz; 320 respondents (160 beneficiaries and 160 nonbeneficiaries) were selected randomly from identified watershed areas. Study reveals that two blocks from each district will be selected randomly for the present study as these blocks are well covered the watershed programme successfully. Altogether eight villages were selected randomly from each district, while four villages from each block were selected and listed which would be obtained from the offices of SDO (Civil), R. D. block headquarter and other related offices. However, it is proposed to select four villages from each block randomly covered the water shed programme / schemes. After selection of the villages, a list of beneficiaries and nonbeneficiaries of KVK will be prepared from each of the selected village. In order to have representative sample from each village a sample of 20 numbers of cases, out of that 10 from beneficiaries and 10 from nonbeneficiaries will be drawn following the purposively random sampling method. This will result in selection of 320 respondents from 8 villages, out of which 160 will be beneficiaries of the schemes and 160 will be non-beneficiaries of the watershed schemes for comparisons.

\section{Results and Discussion}

Table 1 reveals the total percentage category was found maximum on old age group with 
47.81, followed by middle age group with 42.19 per cent and it was recorded least with 10.00 per cent young age group, respectively. Even the chi-square value on both the group viz; beneficiary and non-beneficiary were found to be significant.

Similar studies were find out by the Sharma (2004); Sharma (2004); Sharma (2011); Sangtam and Sharma (2015); Sharma et al., (2016); Shuya and Sharma et al., 2018.

Table 2 reveals that the demography on beneficiaries group the maximum percentage was recorded on medium (60.73), followed by small with 35.29 per cent and it was recorded least with 3.98 on large, while on nonbeneficiaries group the maximum percentage was recorded on medium (57.81), followed by small with 35.15 per cent and it was recorded least with 7.03 on large, respectively.

Even the chi-square value on both the group viz; beneficiary and non-beneficiary were found to be significant. Similar studies were find out by the Sharma (2004); Sharma (2004); Sharma (2011); Sangtam and Sharma (2015); Sharma et al., (2016); Shuya and Sharma et al., 2018.

Table 3 reveals the educational status on beneficiaries group the maximum percentage was recorded on medium (60.15), followed by small with 35.78 per cent and it was recorded least with 4.06 on large, while on nonbeneficiaries group the maximum percentage was recorded on medium (57.70), followed by small with 35.26 per cent and it was recorded least with 7.03 on large, respectively.

Even the chi-square value on both the group viz; beneficiary and non-beneficiary were found to be significant. Similar studies were find out by the Sharma (2002); Sharma (2004); Sharma and Sharma (2008); Sharma (2011); Sharma (2014); Sangtam and Sharma
(2015); Sharma et al., (2016); Pongener and Sharma (2018), Sharma et al., 2018.

Table 4 reveals that the primary on beneficiaries group the maximum percentage was recorded on medium (55.70), followed by small with 41.61 per cent and it was recorded least with 2.68 on large, while on nonbeneficiaries group the maximum percentage was recorded on medium and small both with 44.97 per cent and it was recorded least with 4.14 on large, respectively.

Even the chi-square value on both the group viz; beneficiary and non-beneficiary were found to be significant. Similar studies were find out by the Dhakre and Sharma (2010); Sharma (2011); Shuya and Sharma (2014); Sharma et al., (2016) Sharma et.al., (2018). Table 5 reveals that on beneficiaries group the maximum percentage was recorded on medium (53.50), followed by small with 43.95 per cent and it was recorded least with 2.55 on large, while on non-beneficiaries group the maximum percentage was recorded on small with 48.10 per cent, followed by medium with 47.47 per cent and it was recorded least with 4.43 on large, respectively.

Similar studies were find out by the Sharma (2004); Dhakre and Sharma (2010); Sharma et al., (2016); Sharma et.al. (2018).

Table 6 reveals the tertiary occupation on beneficiaries group the maximum percentage was recorded on medium (61.11), followed by small with 38.89 per cent and it was recorded as zero (nil) on large, while on nonbeneficiaries group the maximum percentage was recorded on medium (61.90), followed by small with 38.10 per cent and on large it was zero (nil), respectively.

Similar studies were find out by the Sharma (2002); Pongener and Sharma (2018), Sharma et al., (2018). 
Table.1 Age of beneficiaries and non-beneficiaries of respondent family

\begin{tabular}{|c|c|c|c|c|}
\hline S. No. & Age & Beneficiaries & Non-beneficiaries & Total \\
\hline \multirow[t]{2}{*}{1.} & \multirow{2}{*}{ Young (<35 years) } & 19 & 13 & 32 \\
\hline & & $(5.94)$ & $(4.06)$ & $(10.00)$ \\
\hline \multirow[t]{2}{*}{2.} & \multirow[t]{2}{*}{ Middle (36 to 50 years) } & 59 & 76 & 135 \\
\hline & & $(18.43)$ & $(23.75)$ & $(42.19)$ \\
\hline \multirow[t]{2}{*}{3.} & \multirow[t]{2}{*}{ Old (51 \& above) } & 82 & 71 & 153 \\
\hline & & $(25.63)$ & $(22.2)$ & $(47.81)$ \\
\hline \multirow{2}{*}{\multicolumn{2}{|c|}{ Total }} & 160 & 160 & 320 \\
\hline & & $(\mathbf{5 0 . 0 0 )}$ & $(50.00)$ & $(100.00)$ \\
\hline & Chi square value & $105.368 ; p=0.392 *$ & $81.462 ; p=0.618^{*}$ & - \\
\hline
\end{tabular}

The figure in the parentheses indicates percentage in total; Asterisk showed non-significant. Data showed significant at $p<0.05$ )

Table.2 Demography of beneficiaries and non-beneficiaries and association

\begin{tabular}{|c|c|c|c|c|c|c|c|}
\hline & Groups & Sample & Child & Female & Male & Total & Average \\
\hline & Small & 72 & 79 & 104 & 136 & 319 & 4.43 \\
\hline & & $(45.00)$ & (8.74) & $(11.50)$ & (15.04) & $(35.29)$ & \\
\hline & Medium & 84 & 125 & 184 & 240 & 549 & 6.53 \\
\hline : & & $(52.50)$ & $(13.82)$ & $(20.35)$ & (26.55) & $(60.73)$ & \\
\hline 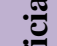 & Large & 4 & 6 & 11 & 19 & 36 & 9 \\
\hline 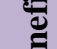 & & $(2.50)$ & $(0.66)$ & $(1.22)$ & (2.10) & (3.98) & \\
\hline 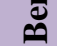 & Total & 160 & 210 & 299 & 3905 & 904 & 5.65 \\
\hline & & (100.00) & $(23.23)$ & (33.07) & (43.70) & (100.00) & \\
\hline & $\begin{array}{l}\text { Chi square } \\
\text { value }\end{array}$ & - & $\begin{array}{c}21.533 \\
p=0.001\end{array}$ & $\begin{array}{c}69.324 \\
p=0.00\end{array}$ & $\begin{array}{l}167.955 \\
p=0.00\end{array}$ & - & - \\
\hline & Small & 76 & 95 & 103 & 117 & 315 & 4.15 \\
\hline & & $(47.50)$ & $(10.60)$ & (11.49) & (13.06) & $(35.15)$ & \\
\hline & Medium & 77 & 173 & 156 & 189 & 518 & 6.73 \\
\hline$\frac{\bar{\pi}}{0}$ & & $(48.12)$ & (19.30) & $(17.41)$ & (21.09) & $(57.81)$ & \\
\hline 佂 & Large & 7 & 18 & 18 & 27 & 63 & 9 \\
\hline ซี & & (4.38) & $(2.00)$ & $(2.00)$ & $(3.01)$ & (7.03) & \\
\hline$\dot{\Xi}$ & Total & 160 & 286 & 277 & 333 & 896 & 5.6 \\
\hline Z & & (100.00) & (31.92) & (30.92) & (37.16) & (100.00) & \\
\hline & $\begin{array}{l}\text { Chi square } \\
\text { value }\end{array}$ & - & $\begin{array}{c}34.459 \\
\mathrm{p}=0.001\end{array}$ & $\begin{array}{c}41.815 \\
p=0.00\end{array}$ & $\begin{array}{c}82.835 \\
\mathrm{p}=0.00\end{array}$ & - & - \\
\hline
\end{tabular}

(The figure in the parentheses indicates percentage in total; Data showed significant at $p<0.05$ ) 
Int.J.Curr.Microbiol.App.Sci (2019) 8(9): 1566-1575

Table.3 Educational status of beneficiaries and non-beneficiaries

\begin{tabular}{|c|c|c|c|c|c|c|}
\hline \multicolumn{2}{|r|}{ Groups } & \multirow{2}{*}{$\begin{array}{c}\text { Illiterate } \\
\\
87\end{array}$} & \multirow{2}{*}{$\begin{array}{c}\text { Primary school } \\
133\end{array}$} & \multirow{2}{*}{$\begin{array}{c}\text { High school } \\
\\
92\end{array}$} & \multirow{2}{*}{$\begin{array}{c}\begin{array}{c}\text { Graduate \& } \\
\text { above }\end{array} \\
14\end{array}$} & \multirow{2}{*}{\begin{tabular}{|c|} 
Total \\
326 \\
\end{tabular}} \\
\hline \multirow{9}{*}{ 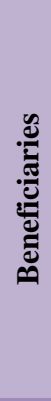 } & \multirow[t]{2}{*}{ Small } & & & & & \\
\hline & & $(9.55)$ & $(14.60)$ & $(10.10)$ & $(1.54)$ & (35.78) \\
\hline & \multirow[t]{2}{*}{ Medium } & 121 & 197 & 192 & 38 & 548 \\
\hline & & (13.28) & (21.62) & (21.07) & $(4.17)$ & $(60.15)$ \\
\hline & \multirow[t]{2}{*}{ Large } & 8 & 10 & 14 & 5 & 37 \\
\hline & & $(0.88)$ & (1.09) & $(1.54)$ & $(0.55)$ & $(4.06)$ \\
\hline & \multirow[t]{2}{*}{ Total } & 216 & 340 & 298 & 57 & 911 \\
\hline & & (23.71) & (37.32) & (32.71) & $(6.26)$ & $(\mathbf{1 0 0 . 0 0})$ \\
\hline & Chi square value & $\begin{array}{c}16.730 \\
p=0.01\end{array}$ & $\begin{array}{c}13.191 \\
\mathrm{p}=0.105^{*}\end{array}$ & $\begin{array}{c}75.652 \\
p=0.00\end{array}$ & $\begin{array}{c}34.531 \\
p=0.00\end{array}$ & - \\
\hline \multirow{9}{*}{ 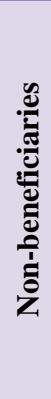 } & \multirow[t]{2}{*}{ Small } & 76 & 158 & 76 & 6 & 316 \\
\hline & & $(8.48)$ & (17.63) & $(8.48)$ & $(0.67)$ & (35.26) \\
\hline & \multirow[t]{2}{*}{ Medium } & 110 & 270 & 100 & 37 & 517 \\
\hline & & $(12.28)$ & $(30.13)$ & (11.16) & $(4.13)$ & (57.70) \\
\hline & \multirow[t]{2}{*}{ Large } & 13 & 33 & 13 & 4 & 63 \\
\hline & & $(1.45)$ & $(3.70)$ & $(1.45)$ & $(0.45)$ & (7.03) \\
\hline & \multirow[t]{2}{*}{ Total } & 199 & 461 & 189 & 47 & 896 \\
\hline & & (22.20) & (51.45) & (21.09) & $(5.25)$ & $(\mathbf{1 0 0 . 0 0})$ \\
\hline & Chi square value & $\begin{array}{c}54.668 \\
\mathrm{p}=0.00\end{array}$ & $\begin{array}{l}124.453 \\
p=0.00\end{array}$ & $\begin{array}{c}41.867 \\
p=0.00\end{array}$ & $\begin{array}{c}33.549 \\
p=0.00\end{array}$ & - \\
\hline
\end{tabular}

(The figure in the parentheses indicates percentage in total; Asterisk showed non-significant.

Data showed significant at $p<0.05$ )

Table.4 Primary occupation of beneficiaries and non-beneficiaries

\begin{tabular}{|c|c|c|c|c|c|c|}
\hline \multicolumn{2}{|c|}{ Groups } & Agriculture & Business & Services & Others & Total \\
\hline \multirow{8}{*}{ 承 } & \multirow[t]{2}{*}{ Small } & 58 & 0 & 4 & 0 & 62 \\
\hline & & (38.93) & $(0.00)$ & $(2.68)$ & $(0.00)$ & (41.61) \\
\hline & \multirow[t]{2}{*}{ Medium } & 61 & 21 & 1 & 0 & 83 \\
\hline & & (40.94) & (14.10) & $(0.67)$ & $(0.00)$ & $(55.7)$ \\
\hline & \multirow[t]{2}{*}{ Large } & 3 & 1 & 0 & 0 & 4 \\
\hline & & $(2.01)$ & $(0.67)$ & $(0.00)$ & $(0.00)$ & $(2.68)$ \\
\hline & \multirow[t]{2}{*}{ Total } & 122 & 22 & 5 & 0 & 149 \\
\hline & & (81.88) & (14.77) & (3.35) & $(0.00)$ & $(\mathbf{1 0 0 . 0 0})$ \\
\hline \multirow{8}{*}{ 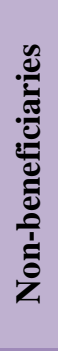 } & \multirow[t]{2}{*}{ Small } & 63 & 13 & 0 & 0 & 76 \\
\hline & & $(37.28)$ & $(7.69)$ & $(0.00)$ & $(0.00)$ & (44.97) \\
\hline & \multirow[t]{2}{*}{ Medium } & 52 & 20 & 4 & 0 & 76 \\
\hline & & (30.77) & (11.83) & (2.37) & $(0.00)$ & (44.97) \\
\hline & \multirow[t]{2}{*}{ Large } & 5 & 2 & 0 & 0 & 7 \\
\hline & & $(2.96)$ & (1.18) & $(0.00)$ & $(0.00)$ & $(4.14)$ \\
\hline & \multirow[t]{2}{*}{ Total } & 120 & 45 & 4 & 0 & 169 \\
\hline & & (71.01) & (26.62) & $(2.37)$ & $(0.00)$ & $(100.00)$ \\
\hline
\end{tabular}

(The figure in the parentheses indicates percentage in total) 
Table.5 Secondary occupation of beneficiaries and non- beneficiaries

\begin{tabular}{|c|c|c|c|c|c|c|}
\hline & Groups & Agriculture & Business & Services & Others & Total \\
\hline & Small & 14 & 50 & 3 & 2 & 69 \\
\hline & & $(8.92)$ & $(31.85)$ & $(1.91)$ & $(1.27)$ & (43.95) \\
\hline$\stackrel{\mathscr{2}}{=}$ & Medium & 23 & 48 & 8 & 5 & 84 \\
\hline 晃 & & $(14.65)$ & $(30.57)$ & $(5.09)$ & $(3.18)$ & $(53.50)$ \\
\hline 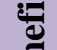 & Large & 1 & 3 & 0 & 0 & 4 \\
\hline 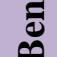 & & $(0.64)$ & (1.91) & $(0.00)$ & $(0.00)$ & $(2.55)$ \\
\hline & Total & 38 & 101 & 11 & 7 & 157 \\
\hline & & (24.20) & (64.33) & (7.01) & $(4.46)$ & (100.00) \\
\hline & Small & 13 & 58 & 4 & 1 & 76 \\
\hline$\stackrel{\mathscr{E}}{*}$ & & $(8.23)$ & $(36.71)$ & $(2.53)$ & $(0.63)$ & (48.10) \\
\hline 疍 & Medium & 24 & 43 & 5 & 3 & 75 \\
\hline 远 & & (15.19) & $(27.22)$ & (3.16) & $(1.89)$ & (47.47) \\
\hline एँ & Large & 2 & 5 & 0 & 0 & 7 \\
\hline$\stackrel{Q}{\Xi}$ & & $(1.26)$ & $(3.16)$ & $(0.00)$ & $(0.00)$ & $(4.43)$ \\
\hline & Total & 39 & 106 & 9 & 4 & 158 \\
\hline & & (24.68) & (67.09) & (5.70) & $(2.53)$ & (100.00) \\
\hline
\end{tabular}

Table.6 Tertiary occupation of beneficiaries and non- beneficiaries

\begin{tabular}{|c|c|c|c|c|c|c|}
\hline & Groups & Agriculture & Business & Services & Others & Total \\
\hline & Small & 0 & 0 & 7 & 0 & 7 \\
\hline & & $(0.00)$ & $(0.00)$ & $(38.89)$ & $(0.00)$ & (38.89) \\
\hline 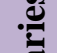 & Medium & 0 & 0 & 5 & 6 & 11 \\
\hline . & & $(0.00)$ & $(0.00)$ & (27.78) & (33.33) & (61.11) \\
\hline 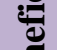 & Large & 0 & 0 & 0 & 0 & $\mathbf{0}$ \\
\hline & & $(0.00)$ & $(0.00)$ & $(0.00)$ & $(0.00)$ & $(0.00)$ \\
\hline & Total & $\mathbf{0}$ & $\mathbf{0}$ & 12 & 6 & 18 \\
\hline & & $(0.00)$ & $(0.00)$ & (66.67) & (33.33) & $(100.00)$ \\
\hline & Small & 0 & 0 & 8 & 0 & 8 \\
\hline & & $(0.00)$ & $(0.00)$ & $(38.10)$ & $(0.00)$ & (38.10) \\
\hline 晃 & Medium & 0 & 0 & 8 & 5 & 13 \\
\hline 를 & & $(0.00)$ & $(0.00)$ & $(38.1)$ & $(23.81)$ & (61.90) \\
\hline تِّ & Large & 0 & 0 & 0 & 0 & 0 \\
\hline$\stackrel{\hat{I}}{=}$ & & $(0.00)$ & $(0.00)$ & $(0.00)$ & $(0.00)$ & $(0.00)$ \\
\hline & Total & $\mathbf{0}$ & $\mathbf{0}$ & 16 & 5 & 21 \\
\hline & & $(0.00)$ & $(0.00)$ & (76.19) & (23.81) & $(100.00)$ \\
\hline
\end{tabular}

(The figure in the parentheses indicates percentage in total) 
Fig.1 Age respondent family demography of beneficiaries and non-beneficiaries

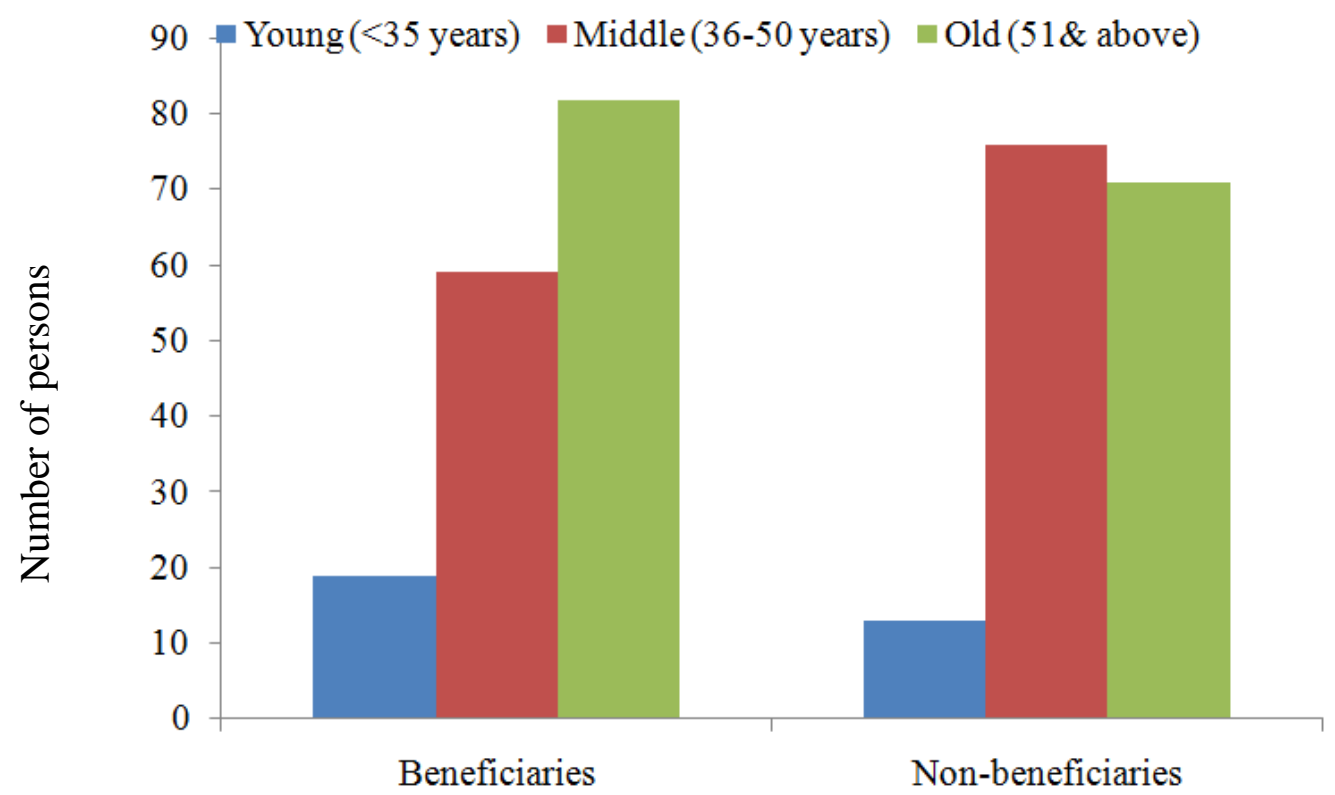

Fig.2 Distribution of respondent family demography of beneficiaries and non-beneficiaries.

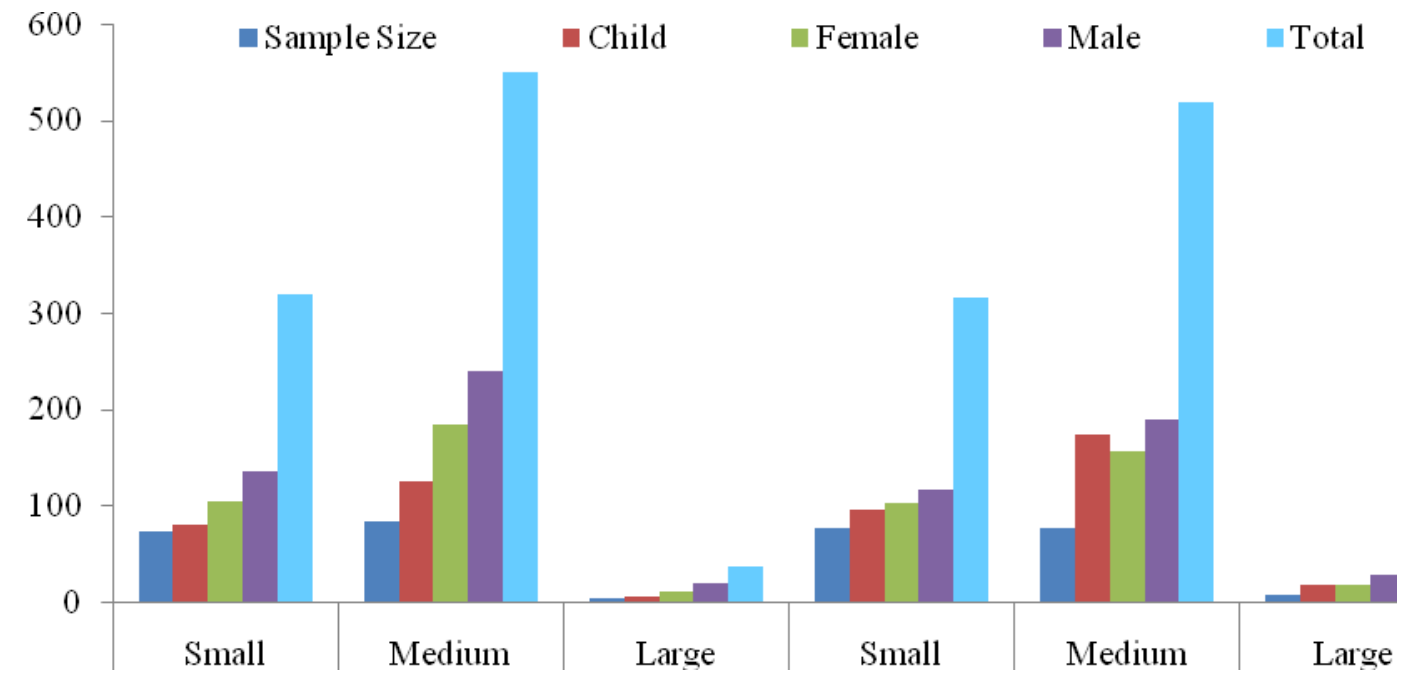


Fig.3 Distribution of respondent's of beneficiaries and non-beneficiaries

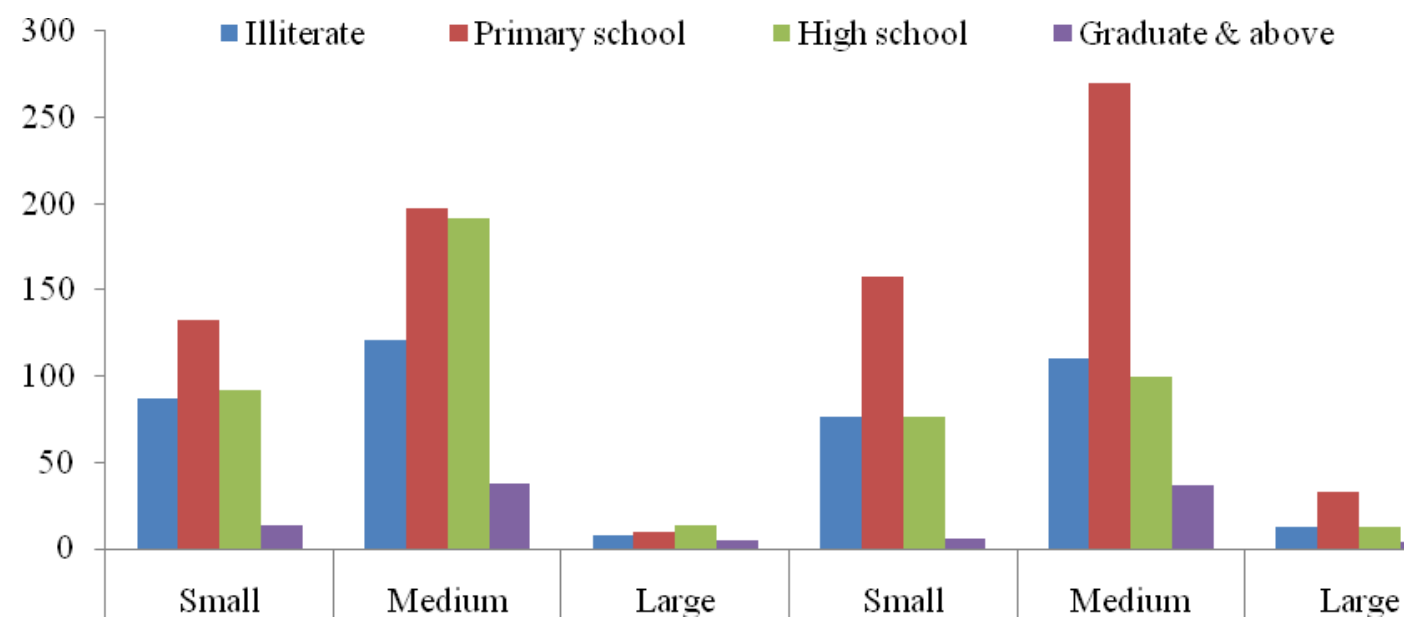

Fig.4 Primary occupation on beneficiaries and non-beneficiaries

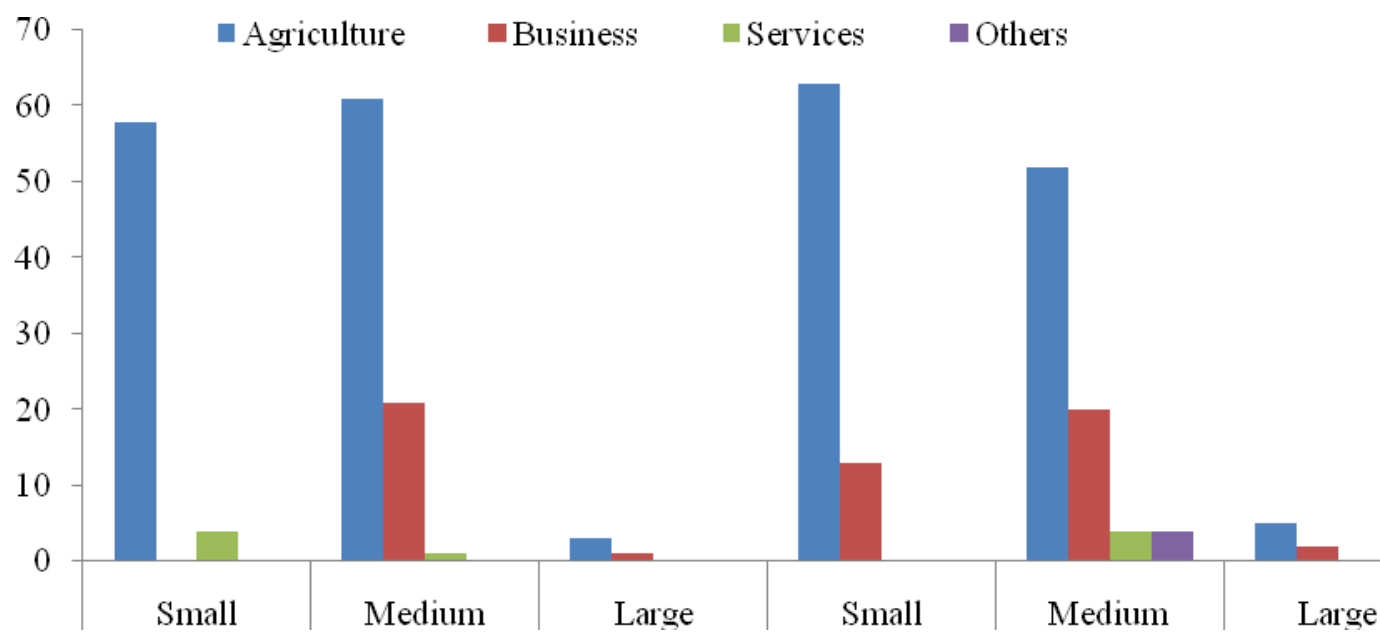


Fig.5 Distribution of occupation on beneficiaries and non-beneficiaries

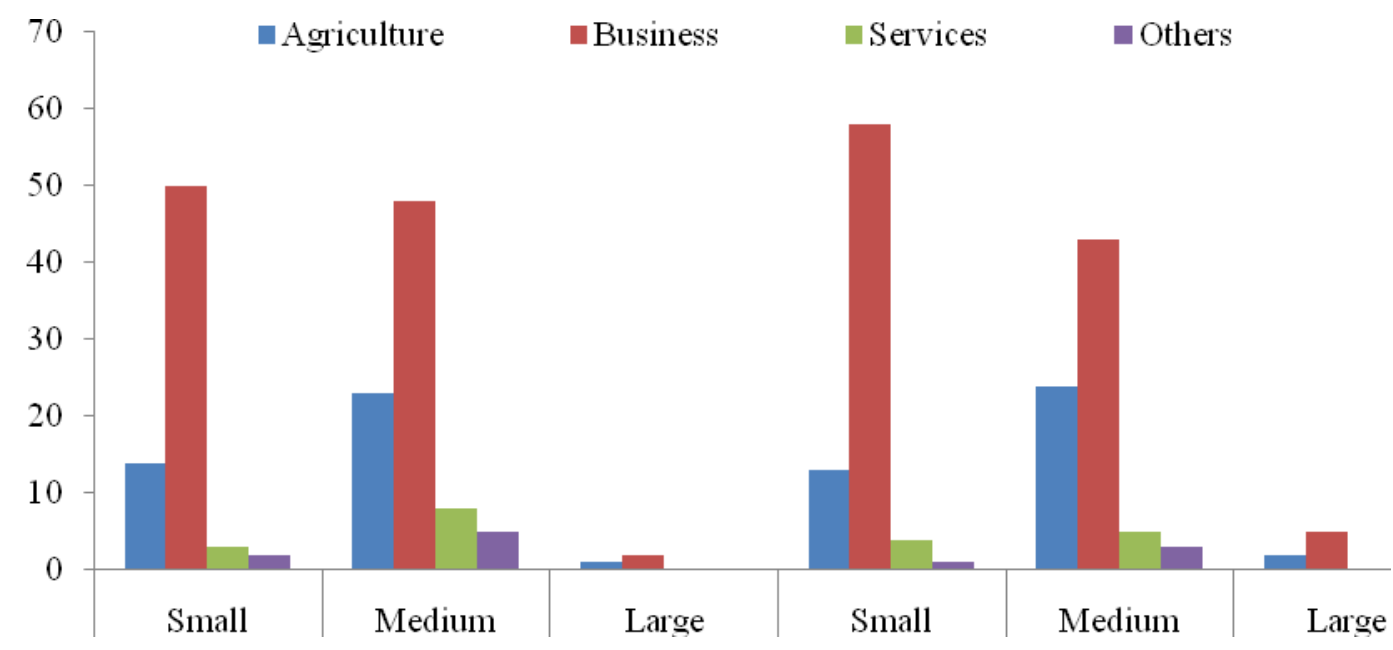

Fig.6 Distribution of tertiary occupation of beneficiaries and non-beneficiaries

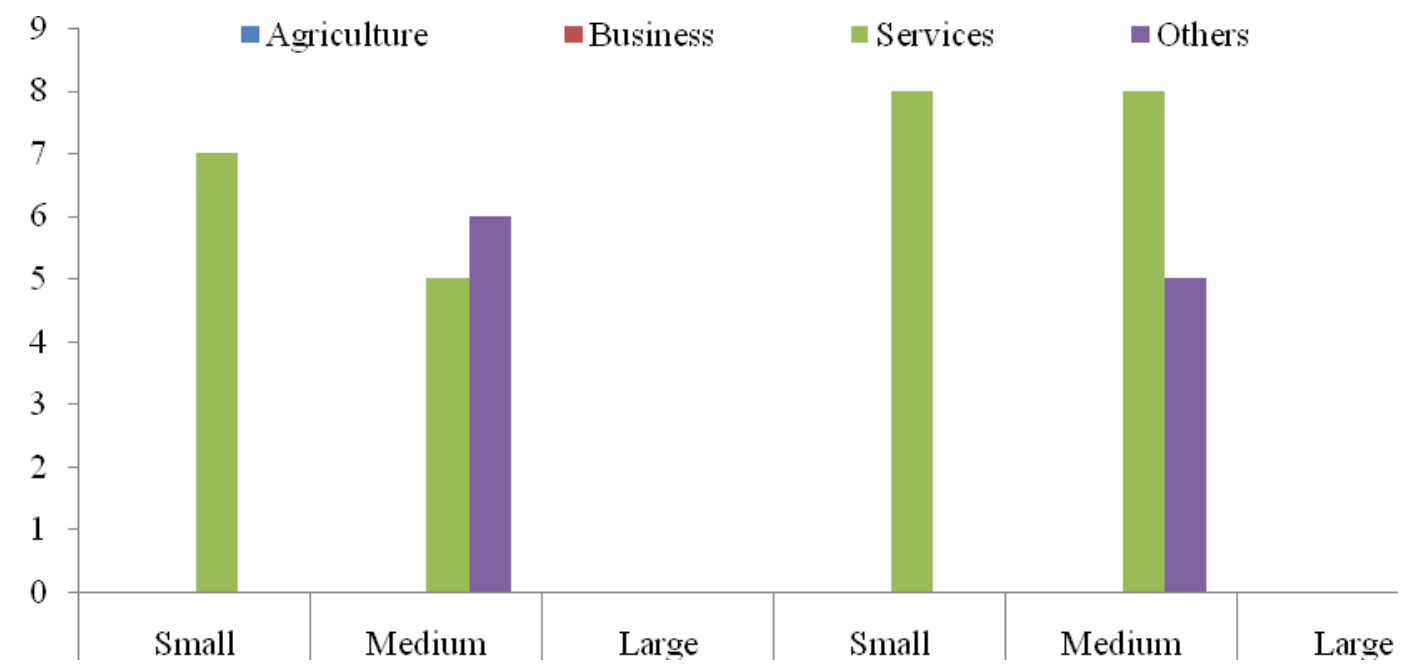

\section{References}

Analogous. 2016. Agricultural Situation in India. Directorate of Economics and Statistics. Ministry of Agriculture, New Delhi.

Analogous. 2017. Statistical Hand of Nagaland Published by Directorate of Economics and Statistics (various issues), Kohima, Nagaland.
Dhakre, D. S. and Sharma, Amod. 2010. Socio-Economic Development in India. Environment and Ecology. 4(1): 24692472.

Pongener, Bendangjungla. and Sharma, Amod. 2018. Constraints Faced by the Fishery Enterprises: A SWOC Analysis. IJCMAS. 7(5). May: 1595-1603.

Sangtam, Likhase. L. T. and Sharma, Amod. 2015. Impact of Bank Finance on 
Employment and Income through Piggery Enterprise in Nagaland. EPRAIJEBR. 3(11). Nov: 273-276.

Sharma, A. 2002. Source and Knowledge on beneficiaries about the purpose of credit - A case study of Agra Region of Uttar Pradesh. Journal of Interacademica. 6(3). July: 374-379.

Sharma, A. 2004. Constraints of Fish Production - A case study in rainfed areas of Uttar Pradesh. Journal of Interacademica. 8(4). October: 639-643.

Sharma, A. and Sharma, Anamika. 2008. Problems faced by the farmers in adoption of improved maize cultivation practices in hills. TJRAR. 8(2): 22-23.

Sharma, Amod. 2011. Economic and Constraints of King Chilli Growers in Dimapur District of Nagaland. Journal of Interacademicia. 15(4): 710-719.

Sharma, Amod. 2012. Inter-state Disparities in Socio-economic Development in North East Region of India. Journal of Agricultural Science. 4(9). September: 236-243.

Sharma, Amod. 2014. Sustainable economic analysis and extent of satisfaction level of King Chilli growers in Nagaland. Agriculture for Sustainable Development. 2(1). June: 188-191.

Sharma, Amod.; Kichu, Yimkumba. and Chaturvedi, B. K. 2016. Economics and Constraints of Pineapple Cultivation in Dimapur District of Nagaland. TJRAR. 16(1). January: 72-75.

Sharma, Amod.; Kichu, Yimkumba. and Sharma, Pradeep. Kumar. 2018.
Sustainable economic analysis and constraints faced by the pineapple growers in Nagaland. Progressive Agriculture. 18(1). February: 27-33.

Sharma, Rajan., Chauhan, Jitendra., Meena, B. S. and Chauhan, R. S. 2015. Problems Experienced By Farmers and Project Officers in Watershed Management. Indian Research Journal of Extension Education. 15(2\&3): 23-27.

Shuya, Keviu. and Sharma, Amod. 2014. Impact and constraints faced by the borrowers of cooperative bank finance in Nagaland. Economic Affairs. 59(4). October: 561-567.

Shuya, Keviu. and Sharma, Amod. 2018. Problems faced by the Borrowers in Utilization and Acquiring of Cooperative Bank Loans in Nagaland. IJED. 14(2). April-June: 52-56.

Tangjang, Avicha. and Sharma, Amod. 2018. Problem faced by the Large Cardamom Growers during production and marketing: A case study of Tirap district of Arunachal Pradesh. IJCMAS. 7(5). May: 2561-2573.

Walling, Imti. and Sharma, Amod. 2015. Impact of SGRY on beneficiaries and non-beneficiaries in Dimapur district of Nagaland. TJRAR. 15(2). August: 90-94.

Walling, Imti.; Sharma, Amod.; Yadav, Mukesh. Kumar.; Rajbhar, Arun, Kumar. and Kalai, Kankabati. 2017. Impact of Agricultural Technology Management Agency on Rural Economy of Nagaland, India. Plant Archiver. 17(2). October: 1511-1516.

\section{How to cite this article:}

Mukesh Kumar Yadav and Amod Sharma 2019. Effects of Socio-Economic and Occupation on Beneficiary and non-Beneficiary Water-shed Management Catchment Areas in the State of Nagaland, India. Int.J.Curr.Microbiol.App.Sci. 8(09): 1566-1575.

doi: https://doi.org/10.20546/ijcmas.2019.809.179 